\title{
SÉRIE "Ekologie"
}

https://doi.org/10.52058/2695-1592-2021-5(5)-84-96

\section{Світлана Пустова}

аспірант кафедри загальної екології, радіобіологї та безпеки життєдіяльності, Національний університет біоресурсів та природокористування України,

м. Київ, Украӥна, е-таil: pustova85@gmail.com, https://orcid.org/0000-0002-3768-2397

\section{Володимир Боголюбов}

доктор педагогічних наук, професор кафедри загальної екології,

радіобіології та безпеки життєдіяльності,

Національний університет біоресурсів та природокористування Украӥни, м. Київ, Україна, e-mail: e-mail: volbog@ukr.net, https://orcid.org/0000-0001-5181-6892

\section{Ольга Попова}

кандидат архітектури, доцент, завідувач кафедри архітектури будівель $i$ споруд та дизайну архітектурного середовища, Харківський національний університет міського господарства імені О.М. Бекетова, м. Харків, Україна, е-таil: Olya133113@gmail.com, https://orcid.org/0000-0002-4559-352X

\section{ОСОБЛИВОСТІ РОЗРОБКИ СТРАТЕГІЇ СТАЛОГО РОЗВИТКУ ТЕРИТОРІАЛЬНИХ ГРОМАД В УКРАЇНІ}

Анотація. Від стабільності і динаміки розвитку територій залежить соціально-економічне зростання держави та рівень ії конкурентоспроможності на теренах світового співтовариства, що є особливо важливим для України в контексті активних інтеграційних процесів. Організація бізнес-процесів в межах територій, методи i напрями використання місцевого потенціалу 
визначаються документами, розробленими органами місцевого самоврядування на основі власних прогнозів, інтересів громади, а також сформованих громадськістю пропозицій. Стратегія сталого розвитку в системі таких документів є основним багатокомпонентним планом, що включає аналіз стану та перспектив зростання територій, пріоритетні вектори діяльності на майбутні періоди, а також прогноз і обгрунтування наслідків від реалізації тактичних заходів. Метою статті $є$ аналіз організаційно-методичних аспектів розробки стратегії сталого розвитку територій в Україні як одного із базових документів, що визначає ефективність поточної діяльності громади та окреслює перспективи іiї соціально-економічного зростання у майбутньому. Дослідження проблематики здійснювалось завдяки застосуванню методів порівняння, абстракції, аналізу, узагальнення, а також графічного i табличного моделювання. Доведено, що формування стратегії є складним процесом, який включає як аналіз соціально-економічних показників розвитку громади, так і визначення місії, цілей, тактики діяльності, а також прогнозування зростання. Кожен із окреслених напрямів роботи є важливим в контексті забезпечення глибинного діагностування; 3 метою підвищення практичної результативності стратегії, процеси іiі формування і реалізації мають бути досконалими. В ході дослідження авторами було окреслено ключові етапи розробки документу, слабкі сторони стратегічного планування на рівні територій та визначено перспективи його вдосконалення в контексті підвищення рівня прозорості та ефективності функціонування громади.

Ключові слова: територіальний розвиток, Стратегія сталого розвитку, стратегічне планування, об'єднана територіальна громада, органи місцевого самоврядування, громадськість, прозорість місцевої влади.

\section{Svitlana Pustova}

Postgraduate student of the Department of General Ecology, Radiobiology and Life Safety National University of Life and Environmental Sciences of Ukraine,

Kiev, Ukraine, e-mail: pustova85@gmail.com, https://orcid.org/0000-0002-3768-2397

\section{Vladimir Bogolyubov}

Doctor of Pedagogical Sciences, Professor of the Department of General Ecology, Radiobiology and Life Safety

National University of Life and Environmental Sciences of Ukraine, Kiev, Ukraine, e-mail:volbog@ukr.net, https://orcid.org/0000-0001-5181-6892

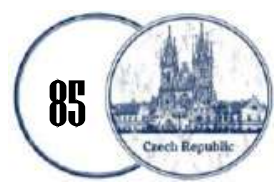




\title{
Olha Popova
}

Candidate of Architecture, assistant professor, Head of the Department of Architecture of Building and Structures and Design of Architectural Environment of O. M. Beketov National University of Urban Economy in Kharkiv, Kharkiv, Ukraine, e-mail: Olya133113@gmail.com, https://orcid.org/0000-0002-4559-352X

\section{PECULIARITIES OF DEVELOPMENT OF STRATEGY OF SUSTAINABLE DEVELOPMENT OF TERRITORIAL COMMUNITIES IN UKRAINE}

\begin{abstract}
The socio-economic growth of the state and the level of its competitiveness on the territory of the world community depend on the stability and dynamics of territorial development, which is especially important for Ukraine in the context of active integration processes. The organization of business processes within the territories, methods and directions of use of local potential are determined by the documents developed by local governments on the basis of own forecasts, interests of community, and also the offers generated by the public. The strategy of sustainable development in the system of such documents is the main multi-component plan, which includes an analysis of the state and prospects of territorial growth, priority vectors for future periods, as well as forecasting and justifying the consequences of tactical measures. The aim of the article is to analyze the organizational and methodological aspects of developing a strategy for sustainable development of territories in Ukraine as one of the basic documents that determines the effectiveness of current community activities and outlines the prospects for its socio-economic growth in the future. The research was carried out through the use of methods of comparison, abstraction, analysis, generalization, as well as graphical and tabular modeling. It has been proven that strategy formation is a complex process that includes both the analysis of socio-economic indicators of community development and the definition of mission, goals, tactics, as well as growth forecasting. Each of the outlined areas of work is important in the context of providing in-depth diagnosis; in order to increase the practical effectiveness of the strategy, the processes of its formation and implementation must be perfect. During the study, the authors outlined the key stages of document development, weaknesses of strategic planning at the territorial level and identified prospects for its improvement in the context of increasing the level of transparency and efficiency of the community.
\end{abstract}

Keywords: territorial development, Sustainable Development Strategy, strategic planning, united territorial community, local self-government bodies, public, transparency of local authorities.

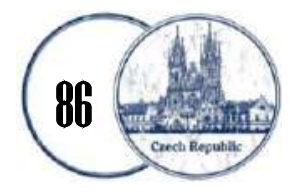


Постановка проблеми. В умовах сьогодення проблематика розробки стратегії сталого розвитку громади полягає у низькій якості та обмеженості інституційного, інформаційного, теоретико-методологічного та ресурсного забезпечення, а також значній мінливості соціально-економічного розвитку як окремих територій, так і держави загалом. В умовах невизначеності доцільною $\epsilon$ пропозиція формалізованого механізму формування, доопрацювання i ухвалення стратегічного плану із чітко визначеними критеріями діагностування поточного стану і перспектив розвитку громади. Враховуючи те, що реформа децентралізації в Україні триває, важливим $є$ сприйняття стратегічного планування і прогнозування територіального зростання як окремого вектора реформаційної діяльності із обов'язковим дотриманням організаційнопрактичних вимог до цього процесу.

Отже, сучасний механізм розробки стратегії сталого розвитку об'єднаних територіальних громад в Україні має стати системним шляхом до управління змінами й досягнення збалансованості потреб, цінностей і інтересів в громаді. Побудова стратегічного плану має грунтується на засадах перманентного партнерства влади і громадськості, забезпечення життєздатності територій та раціональності використання місцевих ресурсів, інтеграції бізнесу, влади і населення у суспільне життя територіальної одиниць, субсидіарності, інноваційності моделей управління розвитком місцевого потенціалу, а також досягнення сумісності і синергії тактичних заходів.

Аналіз останніх досліджень та публікацій. Аналіз особливостей та організаційних аспектів розробки стратегії сталого розвитку громади, а також перспектив підвищення ефективності стратегічного планування на місцевому рівні в контексті створення умов для стабільного соціально-економічного розвитку України $\epsilon$ достатньо актуальною для дослідження сучасними науковцями темою. В контексті обгрунтування необхідності використання стратегій сталого розвитку на рівні громад доцільно визначити передумови поширення стратегічного планування на місцях, основною із сукупності яких $\epsilon$ проведення в Україні реформи децентралізації. А. Умланд досліджує концептуальні основи реалізації адміністративно-територіального реформування i визначає, що децентралізація - це процес, який реально дозволяє протистояти федералізації та сепаратистським тенденціям, необхідний для зміцнення національної економіки [1]. Відповідно, як визначив А. Б. Дирів, відображення тенденцій фінансової, політичної та адміністративної децентралізації у стратегіях сталого розвитку громад забезпечить зміцнення їх конкурентних позицій в перспективі [2, с. 124]. В. Кравців та І. Сторонянська аналізують етапи розробки та практичного застосування стратегії сталого розвитку як документу, що формує основу для раціоналізації економічних процесів в межах громади у довгостроковій перспективі. Науковці визначили,

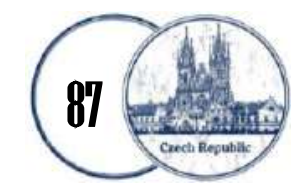


що стратегія $є$ не лише базовим документом, який визначає можливості i перспективи зростання, a i дієвим механізмом управління ефективністю розпорядження власністю вітчизняних територій та ресурсів [3, с. 202]; значну увагу дослідники приділяють аспектам стратегічного просторового планування [3, с. 342]. В контексті динамічних інтеграційних тенденцій науковці, зокрема I. Сторонянська, I. Лещух, М. Мельник, С. Щехлюк, Т. Мединська [4], приділяють значну увагу аналізу практики європейських держав щодо здійснення стратегічного планування регіонального розвитку; метою дослідження зарубіжного досвіду $\epsilon$ виокремлення позитивних європейських практик, які можна застосувати в ході розробки стратегій сталого розвитку вітчизняних громад та оптимізації механізмів фінансування вітчизняних територій. Питання поведінкових закономірностей, притаманних процесу прийняття рішень суб'єктами фінансово-економічних відносин в контексті реалізації стратегії сталого розвитку на рівні регіонів чи громад досліджують Г. Возняк, Л. Беновська [5]. Авторами проаналізовано особливості практичного застосування однієї із трьох моделей прийняття управлінських рішень, а саме класичної, поведінкової чи ірраціональної; доведено, що реалізація ірраціональних рішень органами місцевого самоврядування тягне за собою негативний вплив на розвиток територій. Отже, важливість вивчення та розуміння психології прийняття управлінських рішень під час розробки та реалізації стратегії сталого розвитку полягає у необхідності уникнення найпоширеніших управлінських помилок $[5$, с. 78]. В рамках сучасних реформаційних процесів Я. Білоус [6] здійснює характеристику теоретикометодологічних аспектів розробки стратегії сталого розвитку на рівні окремих громад. П. Саєнко [7] аналізує організацію стратегічного планування на місцях; на основі своїх досліджень науковець виокремив етапи експрес-розробки стратегії соціально-економічного зростання ОТГ.

Виділення невирішених раніше частин загальної проблеми. Праці наведених дослідників відображають особливості процесу розробки стратегії сталого розвитку територій в Україні, проте науковцями не було враховано сучасні соціально-економічні трансформації та ріст значення стратегічного планування на місцях в контексті пост-кризової стабілізації. Окрім того, відбувається реформування не лише адміністративно-територіального устрою України, а i моделей реалізації публічного управління, теоретичні аспекти проведення якого відображено у Стратегії сталого розвитку України до 2030 року [8], Державній стратегії регіонального розвитку на 2021-2027 рр. [9], Цілях сталого розвитку [10]. Проте, вплив сучасних трансформацій та вище окреслених документів на стан стратегічного планування сталого територіального розвитку недостатньо висвітлено в працях сучасних науковців.

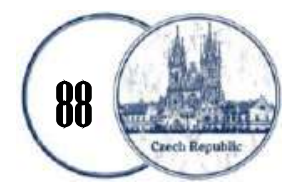


Мета статті. Метою написання наукової статті $\epsilon$ аналіз практичних та методичних аспектів розробки стратегії сталого розвитку територій в Україні як невід'ємного елемента організаційного забезпечення діяльності ОТГ, що визначає ефективність поточної роботи громади та окреслює перспективи ії економічного зростання у майбутньому.

Виклад основного матеріалу. У Державній стратегії регіонального розвитку на 2021-2027 pp. (далі - Державна стратегія) [9], визначено, що стратегія сталого розвитку територій розробляється 3 метою зміцнення фінансових можливостей громади і визначення компетенцій органів місцевого самоврядування; окрім того, стратегія сприяє вибору із сукупності альтернативних найбільш ефективні механізми стимулювання економічної активності. Ретельно продумала, фінансово обгрунтована стратегія сталого регіонального чи місцевого розвитку виступає організаційним підгрунтям для досягнення головної цілі діяльності органів місцевого самоврядування - підвищення якості життя населення громади і забезпечення його високим рівнем соціальних та адміністративних послуг. Державна стратегія відображає пріоритетні напрями діяльності в контексті стимулювання сталого місцевого розвитку, а також концептуальні основи організації стратегічного планування на місцях.

Враховуючи вибір Україною євроінтеграційного курсу, розробка i прийняття Державної стратегії відбувалось на основі врахування успішних європейських практик у сфері стратегічного планування розвитку територій, а також документів, що визначають формалізований механізм управління соціально-економічним зростанням регіонів i громад. Значний вплив на законотворчі процеси в Україні мала Стратегія «Европа - 2020» [11]. Цим планом було визначено базові принципи для розробки стратегії сталого розвитку об’єднаної територіальної громади (далі -ОТГ) (рис. 1):

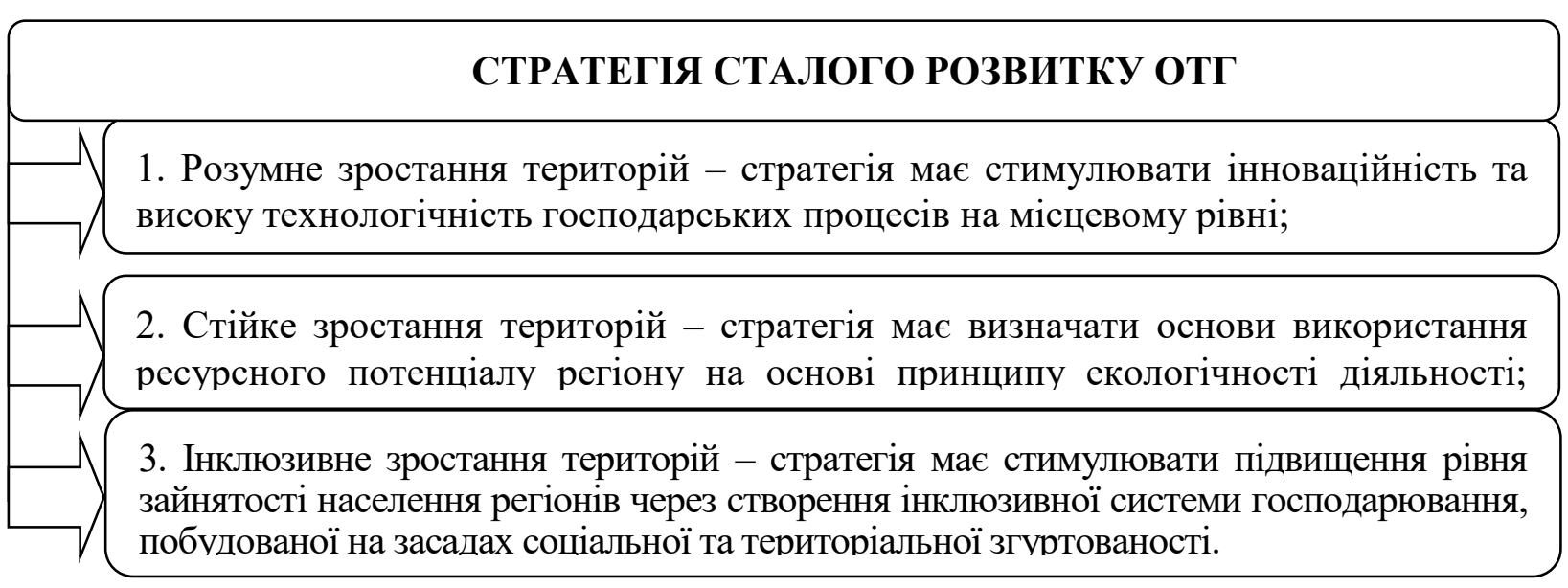

Рис. 1. Принщипи сталого розвитку територій (згідно із Стратегією «Свропа-2020»)

Джерело: складено авторами за даними $[11 ; 12$, с. 9]. 
3 метою формалізації процесу розробки стратегії сталого розвитку ОТГ доцільно використовувати методики планування, прогнозування, а також поточного та попереднього контролю; їх застосування забезпечить формування ефективного багатокомпонентного стратегічного плану діяльності громади на майбутні роки та моніторинг результативності розробленої стратегії в ході іiі практичного втілення.

Основними етапами створення стратегічного плану є такі:

1. Формування організаційно-методичного та інституційного забезпечення діяльності громади на майбутні роки.

2. Проведення аналізу поточного стану та динаміки основних соціально-економічних показників розвитку громади; формування профілю ОТГ - дослідження зовнішнього оточення громади 3 метою виявлення потенційних можливостей для сталого розвитку, а також аналіз не лише соціально-економічних, а і демографічних тенденцій, які дають підставу для прогнозування стабільності цих тенденцій на період планування.

3. Визначення місії, бачення, стратегічних напрямів діяльності ОТГ.

4. Розробка операційних цілей діяльності ОТГ, завдань, планів тактики дій.

На етапах 3 та 4 необхідно здійснювати планування, спираючись на сильні сторони громади та долаючи слабкі, враховуючи шанси появи нових можливостей та страхуючись від загроз, виникнення яких $є$ неминучим в ході реалізації стратегії сталого розвитку. Місія, стратегічні напрями діяльності, а також тактичні завдання і дії мають бути узгодженими; досягнення кожної із основних цілей має здійснюватись на засадах збереження ієрархії напрямів діяльності громади, а також дотримання термінів, визначених на основі реальних перспектив та обсягах залучення ресурсів, необхідних для досягнення результату.

5. Громадське обговорення та ухвалення стратегії сталого розвитку ОТГ - визначення амбітної, але реалістичної динаміки соціально-економічного зростання громади, яким іiї хоче бачити населення ОТГ.

6. Контроль за реалізацією стратегії та динамікою досягнення визначених орієнтирів роботи громади з боку органів влади та громадськості. На цьому етапі необхідно приділити значну увагу створенню ефективної системи контролю і моніторингу проміжних результатів реалізації стратегії сталого розвитку ОТГ. Практичну результативність мають методи кількісного та якісного аналізу показників зростання громади, а також обгрунтування їх динаміки. Окрім традиційних механізмів контролю в умовах цифровізації суспільства доцільним $є$ використання діджитал-інструментів, інновацій та інформаційно-комунікаційних технологій (далі-IКТ), завдяки яким можна

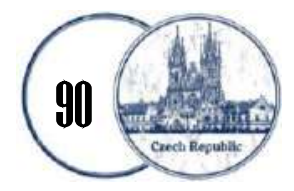


відслідковувати процес реалізації стратегії сталого розвитку території та корегувати його при зміні зовнішніх чи внутрішніх факторів в реальному часі.

Перший етап $\epsilon$ підготовчим, проте особливо важливим в контексті створення сучасного функціонального забезпечення для діяльності громади. Від рівня організованості роботи на цьому етапі залежить загальна результативність, прозорість і справедливість роботи ОТГ.

Першим завданням на цьому етапі $є$ опрацювання загальнонаціональних документів, які відображають стратегічне бачення функціонування держави, а також регіонів як самодостатніх одиниць в структурі національної економіки. Такими документами на сьогодні є Державна стратегія [9], Стратегія сталого розвитку України до 2030 [8] та Цілі сталого розвитку [10]; вони містять обгрунтування векторів діяльності держави та аналіз макроекономічних тенденцій. Також доцільним $є$ наукове обгрунтування стратегічного вибору діяльності та розробка єдиної методологічної бази для підготовки стратегії, що необхідно в контексті ув'язки між собою вище зазначених стратегічних документів та територіальних програм (комплексних та галузевих).

Другим завданням на цьому етапі $\epsilon$ процес фізичної підготовки приміщення, яке буде використано в якості будівлі для роботи адміністративного персоналу, а також співпраці з громадськістю. Цей процес має важливе значення в контексті відновлення довіри і прозорості відносин між владою і громадянами, хоча його роль досить часто недооцінюють. Основними критеріями будівлі мають бути комфорт, доступність і інклюзивність, енергоефективність, екологічність та естетичність [13]. Необхідність їх дотримання пов'язана із потребою у демонстрації для громадян перспектив соціально-економічного зростання громад України. Створення таких «Центрів сталого розвитку» $\epsilon$ сигналами побудови нових сучасних інституцій, модернізація чи будівництво яких мають на меті спростити співпрацю суспільства і влади, забезпечити завчасне волевиявлення громадян, сформувати сприятливі умови для підвищення значущості їх думки і інтересів, а також підвищити рівень прозорості роботи із населенням ОТГ. Отже, на нашу думку, будівля має відповідати наступним критеріям:

1) по-перше, приміщення має бути облаштоване за принципом «відкритого простору» і повністю відповідати вимогам діючого законодавства (зокрема, Закону України «Про адміністративні послуги» [14], а також внутрішнім Положенням, Регламентам роботи, ключові аспекти яких мають бути висвітлені у стратегії сталого розвитку громади);

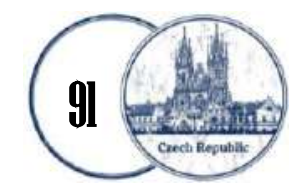


2) по-друге, приміщення має бути максимально відкритим, хоча закрита частина також має бути передбачена (вона необхідна для опрацювання та збереження документів). Відкрита частина $\epsilon$ секційною i включає такі складові: сектор прийому громадян (який функціонує 3 метою ознайомлення громадян із організаційною структурою приміщення, а також їх консультування щодо питань роботи Центру); сектор інформування і сектор очікування (які працюють $з$ метою забезпечення комфортного очікування на обслуговування та надання вичерпної інформації громадянам щодо питань, які в них виникають; сектор має бути облаштований інформаційними стендами 3 актуальними даними, комфортними столами, стільцями, телефонами, факсимільними апаратами, а також канцелярськими товарами, які необхідні для громадян в процесі заповнення документів); сектор консультування і обслуговування (який має бути облаштовано за принципом відкритості розміщення робочих місць, що забезпечить організацію роботи на засадах прозорості та відкритості умов до спілкування з громадянами).

Окрема частина будівлі має бути забезпечена залами для зустрічей адміністративних працівників, органів місцевого самоврядування та інших осіб, що мають значний вплив на структуру політичних i соціально-економічних відносин в межах громади. Таких залів доцільно робити декілька. Вони мають бути закритими, проте містити відокремлений простір для громадян, які виявили бажання чи мають потребу бути присутнім на вирішенні певних питань територіального значення. Доцільним є використання цих приміщень для зустріч із партнерами (зокрема, інвесторами, які приймають активну участь у житті громади) чи органами державної і регіональної влади.

3 метою дотримання принципу сталості розвитку громади має бути враховано тенденції екологізації діяльності в державі, що передбачено Основними засадами державної екологічної політики України на період до 2030 року. Документ відображає необхідність підпорядкованості економічної діяльності екологічним пріоритетам [15]. Відповідно, стратегія сталого розвитку ОТГ має підтримувати відповідальне ставлення громади до ресурсного потенціалу, а також визначати першочергову важливість енергоефективного та екологічно безпечного будівництва (рис. 2). 
Věda a perspektivy № $5(5) 2021$

ISST 2695-1584 (Print)

ISST 2695-1592 (Online)

\section{Енергоефективне та екологічно орієнтоване будівництво в контексті управління прозорістю використання місцевих ресурсів}

1. Застосування матеріалів та обладнання в ході будівництва чи модернізації приміщення лише тих, що виробляються на території ОТГ;

2. Використання лише екологічно чистих та безпечних для людей і навколишнього середовища матеріалів;

3. Оптимізація і мінімізація затрат протягом будівництва та експлуатації будівлі;

4. Демонстрація практики та створення прикладу для громадян щодо застосування енергоефективних технологій та матеріалів у будівництві;

7. Використання відновлювальних джерел енергії для повного чи часткового забезпечення потреб будівлі;

8. Цілорічне підтримання комфортних умов для відвідувачів та персоналу;

9. Забезпечення доступності для осіб з обмеженими можливостями, а також усіх мешканців громади незалежно від віку, статі чи соціальної групи.

Pис. 2. Принципи створення сучасної будівлі для діяльності ОТГ Джерело: складено авторами за даними [13].

Таким чином, в стратегії сталого розвитку ОТГ доцільно відобразити практичні аспекти створення екологічно ефективної будівлі відкритого типу для організації роботи громади, яка матиме сукупність переваг, а саме: сприяння ефективній комунікації, формування оптимального середовища для інклюзивного функціонування ОТГ із включенням громадян до суспільного життя та творчого обміну пропозиціями, практичними ідеями щодо розвитку громади; збереження командного духу, який підкреслить важливість як органів влади у системі управління громадою, так і громадян - осіб, які корегують реалізацію управлінських рішень; гнучкість роботи ОТГ, зокрема можливість зміни просторової організації для швидкого колективного прийняття рішень, обговорення організаційно-практичних аспектів діяльності громади, не змінюючи робочого місця та легкість задіяння громадян до такого обговорення.

Висновки. 3 огляду на проведений аналіз можна зробити висновок, що розробка стратегії сталого розвитку громади $\epsilon$ не просто складним процесом, а багатокомпонентним механізмом, який визначає джерела забезпечення зростання територій, методи раціоналізації управління потенціалом громади, аспекти підвищення прозорості відносин між владою і громадськістю. В результаті адміністративної і фінансової децентралізації в Україні відбулось створення оптимального бізнес-клімату для розвитку територій, а тому на

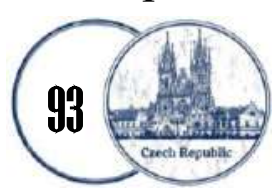


сьогодні пріоритетним завданням $є$ формування стратегічного бачення щодо соціально-економічного зростання громад i вдосконалення практики досягнення цілей сталого розвитку.

\section{Лimepamypa:}

1. Умланд А. Чотири геополітичні виміри децентралізації України. Дзеркало тижня. Україна. 2019. Available at: https://dt.ua/internal/chotiri-geopolitichni-vimiri-decentralizaciyiukrayini-299352_.html (дата звернення 09.10. 2021 p.).

2. Дирів А. Б. Впровадження реформи децентралізації для забезпечення сталого місцевого розвитку. Право та державне управління. 2019. № 1 (34). Том 1. С. 124-128.

3. Територіальні громади в умовах децентралізації: ризики та механізми розвитку: монографія / за ред. Кравціва В. С., Сторонянської І. З. Львів: ДУ «Інститут регіональних досліджень імені М. І. Долішнього НАН України, 2020. 531 с.

4. Storonyanska I., Melnyk M., Leshchukh I., Shchehlyuk S., \& Medynska T. The Efficiency of Financing the Regional Smart-Specialization Strategies' Implementation from the EU Structural Funds. European Journal of Sustainable Development. 2021. №10 (2). pp. 241-255. doi: https://doi.org/10.14207/ejsd.2021.v10n2p241

5. Возняк Г.В., Беновська Л.Я. Обгрунтування поведінкових закономірностей прийняття рішень суб'єктами фінансово-економічних відносин на регіональному рівні. Регіональна економіка. 2021. №1(99). C.72-80.doi: https://doi.org/10.36818/1562-0905-2021-1-8

6. Білоус Я. Ю. Стратегічне планування розвитку територіальних громад: підходи та етапи. Вісник східноукраїнського національного університету імені Володимира Даля. 2017. №2 (232). С. 14-18.

7. Саєнко П. О. Експрес-розробка стратегічного плану сталого розвитку новоутвореної територіальної громади. Вісник східноукраїнського національного університету імені Володимира Даля. 2016. № 6 (230). С. 120-123.

8. Стратегія сталого розвитку України до 2030 року (проект). United Nations Development Programme, 2017. 112 c. Available at: https://www.undp.org/content/dam/ukraine/ docs/SDGreports/UNDP_Strategy_v06-optimized.pdf (дата звернення 09.10.2021р.)

9. Про затвердження Державної стратегії регіонального розвитку на 2021-2027 роки: Постанова Кабінету Міністрів України від 05.08.2020 р. №695. Законодавство України: сайт. Available at: https://zakon.rada.gov.ua/laws/card/695-2020-\%D0\%BF (дата звернення 09.10.2021).

10. Про Цілі сталого розвитку України на період до 2030 року: Указ Президента України від 30.09.2019 p. № 722/2019. Законодавство України: сайт. Available at: https://zakon.rada.gov.ua/laws/card/722/2019 (дата звернення 09.10.2021р.)

11. The European Union explained: Europe 2020: Europe's growth strategy. Luxembourg: Publications Office of the European Union, 2013. 12 p.

12. Šostar M., Andrlic B., Popov O. Effect of Europe Strategy 2020 and national regional policies on smart cities development. Bulletin of the Odessa State Academy of Civil Engineering and Architecture. 2019. №77. pp. 9-20. doi: 10.31650/2415-377X-2019-77-9-20

13. Кращі практики та поради щодо створення енергоефективних ЦНАП в ОТГ, 2019. Available at: https://tsnap.ulead.org.ua/wp-content/uploads/2019/11/Posibnyk-z-energoefektyvnosti- tastalogo-rozvytku.pdf (дата звернення 09.10.2021р.)

14. Про адміністративні послуги: Закон України від 06.09.2012 №5203-VI. Законодавство України: сайт. Available at: https://zakon.rada.gov.ua/laws/card/5203-17 (дата звернення 09.10.2021р.)

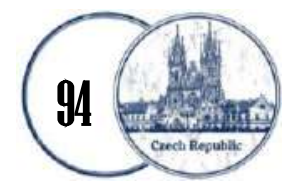


Věda a perspektivy № $5(5) 2021$

ISSN 2695-1584 (Print)

ISST 2695-1592 (Online)

15. Про Основні засади (стратегію) державної екологічної політики України на період до 2030 року: Закон України від 28.02.2019 р. № 2697-VIII. Законодавство України: сайт. Available at: https://zakon.rada.gov.ua/laws/card/2697-19 (дата звернення 09.10.2021р.)

\section{References:}

1. Umland A. (2019), "Four geopolitical dimensions of decentralization of Ukraine", Dzerkalo tyzhnja. Ukrai'na, available at: https://dt.ua/internal/chotiri-geopolitichni-vimiridecentralizaciyiukrayini-299352_.html (Accessed 09 October 2021) [in Ukrainian].

2. Dyriv A. B. (2019), "Implement decentralization reform to ensure sustainable local development", Pravo ta derzhavne upravlinnja, 1 (34), 124-128 [in Ukrainian].

3. Kravciv V. S., Storonjans'ka I. Z. (Eds.) (2020), Terytorial'ni gromady v umovah decentralizacii': ryzyky ta mehanizmy rozvytku [Territorial communities in the conditions of decentralization: risks and mechanisms of development], DU «Instytut regional'nyh doslidzhen' imeni M. I. Dolishn'ogo NAN Ukrai'ny, Lviv, Ukraine [in Ukrainian].

4. Storonyanska I., Melnyk M., Leshchukh I., Shchehlyuk S., \& Medynska T. (2021), "The Efficiency of Financing the Regional Smart-Specialization Strategies' Implementation from the EU Structural Funds", European Journal of Sustainable Development, 10(2), 241-255. https://doi.org/10.14207/ejsd.2021.v10n2p241

5. Voznjak G. V., Benovs'ka L. Ja. (2021), "Substantiation of behavioral patterns of decision-making by financial and economic entities at the regional level.", Regional'na ekonomika, 1(99), 72-80. doi: https://doi.org/10.36818/1562-0905-2021-1-8 [in Ukrainian].

6. Bilous Y.Y. (2017), "Strategic planning of the territorial communities development: approaches and stages", Visnyk of Eastern Ukrainian National University named after Volodymyr Dahl, 2 (232), 14-18 [in Ukrainian].

7. Saenko P.O. (2016), "Express development of a strategic plan for sustainable development of the newly formed territorial communities", Visnyk of Eastern Ukrainian National University named after Volodymyr Dahl, 6 (230), 120-123 [in Ukrainian].

8. United Nations Development Programme (2017), "Strategy of sustainable development of Ukraine through 2030 (project)", available at: https://www.undp.org/content/dam/ukraine/docs/ SDGreports/UNDP_Strategy_v06-optimized.pdf (Accessed 09 October 2021) [in Ukrainian].

9. Pro zatverdzhennja Derzhavnoi' strategii' regional'nogo rozvytku na 2021-2027 roky [On approval of the State Strategy for Regional Development for 2021-2027] (2020). Resolution of the Cabinet of Ministers of Ukraine, adopted on 2020, 5 May, №695. Legislation of Ukraine: Website. Retrieved from https://zakon.rada.gov.ua/laws/card/695-2020-\%D0\%BF (Accessed 09 October 2021) [in Ukrainian].

10. Pro Cili stalogo rozvytku Ukrai'ny na period do 2030 roku [On the Goals of sustainable development of Ukraine for the period up to 2030] (2019). Decree of the President of Ukraine, adopted on 2019, 30 September, № 722/2019. Legislation of Ukraine: Website. Retrieved from https://zakon.rada.gov.ua/laws/card/722/2019 (Accessed 09 October 2021) [in Ukrainian].

11. European Commission (2013), The European Union explained: Europe 2020: Europe's growth strategy, Publications Office of the European Union. Luxembourg.

12. Šostar M., Andrlic B., Popov O. (2019), "Effect of Europe Strategy 2020 and national regional policies on smart cities development", Bulletin of the Odessa State Academy of Civil Engineering and Architecture, 77, 9-20. doi: 10.31650/2415-377X-2019-77-9-20

13. Krashhi praktyky ta porady shhodo stvorennja energoefektyvnyh CNAP v OTG (2019), available at: https://tsnap.ulead.org.ua/wp-content/uploads/2019/11/Posibnyk-z-energoefektyvnostita-stalogo-rozvytku.pdf (Accessed 09 October 2021) [in Ukrainian].

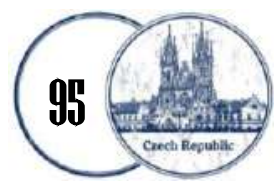


